\title{
VEGETABLE PROTEIN BLEND TECHNOLOGY FOR VEGETARIAN SAUSAGES
}

\author{
H. NAN; \\ N. V. KONDRATJUK, PhD, Associate Professor; \\ T. M. STEPANOVA, PhD, Associate Professor; \\ O. V. AFANASIIEV; \\ K. I. SYTNYK; \\ A. V. DYSHUK; \\ K. YE. SUPRUNENKO \\ (Sumy National Agrarian University)
}

\begin{abstract}
Annotation. The article is devoted to the current topic of protein deficiency in the human body. This review summarizes the main results of studies evaluating the properties of the cultivated fungi proteins and amaranth. The high biological value of proteins makes it possible to obtain mixtures (blends), which can be used to produce vegetarian sausages with improved functional properties. The article presents the possibility of developing a technology of blends based on plant materials by introducing plant materials with high biological value. The developed blends will have a balanced amino acid composition and will contain an increased amount of squalene.
\end{abstract}

Keywords: protein deficiency, cultivated mushrooms, amaranth, vegetarian sausages, squalene.

Formulation of the problem in a general form. Currently, there is a persistent tendency to improve consumed food products by creating new formulas and technologies. The reason for this was the continuous technological progress in the food industry. Despite the identified positive trends in the development and improvement of technologies, the question of insufficient intake of protein food remains rather acute. A general decrease in the consumption of meat and dairy products was noted even in countries with a high income level [1]. Taking into account the fact that the efficiency of protein metabolism in the human body largely depends on their qualitative and quantitative presence in food. In the body, tissue proteins begin to break down when proteins enter below the recommended norms. The development of amino acid-balanced products made from affordable and fast-growing raw materials has become extremely important [2].

Analysis of recent research and publications. As noted earlier, protein intake for a living organism is a factor in development and growth. The quality of food protein is characterized by its biological value, degree of purity of utilization, amino acid composition, digestibility coefficient, etc [3]. The absence of at least one essential amino acid in the food causes a negative nitrogen balance. This causes dysfunctions of the central nervous system, can lead to stunting and severe clinical consequences [2]. This became the basis of an analytical study of information about existing trends in the use of vegetable protein, as a worthy alternative to animal protein. The degree of approximation of the amino acid rate of the developed products to the "ideal" protein was taken into account during the search for existing technological solutions.

Vegetable raw materials, as a source of protein, have several advantages compared to raw materials of animal origin, such as availability, minimal costs for storage and transportation, cost-effectiveness in obtaining and processing, the effectiveness of direct use as food [3]. In particular, concentrates, hydrolysates, and isolates, as purified forms of plant proteins, have a neutral taste and smell, which allows us to consider them as the best matrices for creating improved or new flavoring compositions.

It should be remembered that when using highquality animal protein, saturated fatty acids and cholesterol get into the human body with it. They increase the risk of developing cardiovascular disease. Protein products of plant origin have a lower proportion of saturated fats, contain 
polyunsaturated fatty acids in large quantities [4].

In addition, the functional and technological properties of plant protein isolates, hydrolysates, and concentrates allow them to be included in many food products based on raw materials of animal origin and not only as components enriching amino acids, but also as stabilizers, structure-forming agents, moisture-binding and water-retaining agents. This allows you to get food products with improved quality indicators and increased digestibility. Thus, for a long time there are products that maintain a balance between animal and plant proteins. Scientists from different countries are successfully solving the problem of balanced meat and vegetable products [5-9]. Ways to increase the nutritional value of meat products by enriching the amaranth protein with a hydrolyzate have been proposed [10].

The authors [11] developed new recipes for meat and vegetable semi-finished products of increased biological value, by combining plant materials (hydrated lentils, oyster mushrooms, cabbage, carrots, pumpkins and celery) with traditional meat. They proposed food compositions that have a reduced calorie content (due to added dietary fiber), a high content of biologically active substances (due to the high content of vitamins and antioxidants), and an improved amino acid composition.

The technology of meat-and-vegetable semifinished products of functional purpose with a partial replacement of meat raw materials with highgrade vegetable protein due to the use of lupine flour is also known [12].

The increased nutritional value, functional properties and economic feasibility of creating a combined meat and vegetable products using grain raw materials are justified by the authors [13]. At the same time, high functional and technological properties of minced systems, an increase in the output of finished products without reducing their biological value and organoleptic characteristics were noted.

The author [14] has developed a technology for frozen semi-finished meat products, using animal- based emulsifiers of acylglycerol nature, as well as dry mixes based on food polysaccharide-based hydrocolloids. This allowed them to get products with stable indicators of quality and safety.

The author [15] has proposed methods for stabilizing the functional and technological characteristics of semi-finished products for combined meat products. One of the main proposed routes was the introduction of mushroom raw materials. This approach made it possible to expand the range of these products and to obtain a product not only with standard indicators of quality, but also with economic advantages.

The authors [16] have successfully introduced the proteins of cultivated mushroom raw materials while creating innovative meat products. It was described in the work that introducing up to $35 \%$ of mushroom raw materials into the meat stuffing does not worsen the organoleptic characteristics of the developed meat products, which contributes to the expansion of the assortment group of the proposed products. The result of an analytical study was the formation of a raw sources of vegetable protein database with their quantitative and qualitative assessment of amino acid content. The information received has become the basis for the modeling of blends for the development of technology for vegetarian sausages $[17,18]$.

Numerous studies by scientists have shown that cultivated mushrooms are one of the valuable sources of plant proteins. Their amino acid composition is the most perfect and acceptable of all existing proteins of plant origin, since it includes all the essential amino acids. In the table. 1 shows the amino acid composition of proteins of various origins [19].

These data indicate that the amino acid composition of cultured fungi is high in glutamic and aspartic acids, arginine, leucine, phenylalanine, alanine, serine, glycine, and threonine. Comparing the data of the reference protein with the data of cultivated mushrooms, we can conclude that the mushroom protein is optimal in its composition and can be used in the manufacture of food products to maintain the daily protein content [20].

Table 1

The composition of the essential amino acids of certain food proteins

\begin{tabular}{|c|r|r|r|r|r|r|r|r|}
\hline \multirow{2}{*}{$\begin{array}{c}\text { Name of raw } \\
\text { materials }\end{array}$} & Valine & Isoleucine & Leucine & $\begin{array}{c}\text { Methionine }+ \\
\text { cysteine }\end{array}$ & Threonine & Tryptophan & $\begin{array}{c}\text { Phenyl } \\
\text { alanine }+ \\
\text { tyrosine }\end{array}$ & \begin{tabular}{c} 
Lysine \\
\hline Beef
\end{tabular} \\
\cline { 2 - 9 }$y$ & 5,70 & 4,20 & 8,00 & 3,80 & 4,30 & 1,10 & 7,90 & 8,10 \\
\hline Pork & 5,60 & 4,50 & 7,90 & 3,00 & 4,40 & 1,10 & 6,80 & 8,30 \\
\hline
\end{tabular}


Cont. table 1

\begin{tabular}{|c|c|c|c|c|c|c|c|c|}
\hline \multirow[b]{2}{*}{$\begin{array}{l}\text { Name of raw } \\
\text { materials }\end{array}$} & \multicolumn{8}{|c|}{ The content of essential amino acids in $\mathrm{g}$ per $100 \mathrm{~g}$ of protein } \\
\hline & Valine & Isoleucine & Leucine & $\begin{array}{c}\text { Methionine } \\
\text { cysteine }\end{array}$ & Threonine & Tryptophan & $\begin{array}{c}\text { Phenyl } \\
\text { alanine + } \\
\text { tyrosine }\end{array}$ & Lysine \\
\hline Chicken & 4,10 & 4,20 & 8,20 & 3,40 & 4,00 & 1,00 & 6,80 & 7,70 \\
\hline Marine fish & 5,00 & 4,50 & 8,60 & 4,10 & 4,50 & 1,10 & 6,20 & 9,30 \\
\hline River fish & 4,90 & 4,20 & 7,90 & 3,20 & 2,20 & 2,30 & 4,80 & 8,20 \\
\hline $\begin{array}{c}\text { Soy } \\
\text { hydrolyzate }\end{array}$ & 4,09 & 4,25 & 6,70 & 2,00 & 3,13 & 1,11 & 7,50 & 5,32 \\
\hline $\begin{array}{c}\text { Pea } \\
\text { hydrolyzate }\end{array}$ & 4,00 & 4,30 & 8,10 & 2,30 & 3,00 & 0,90 & 8,20 & 6,10 \\
\hline $\begin{array}{c}\text { Rice } \\
\text { hydrolyzate }\end{array}$ & 5,02 & 5,83 & 8,10 & 4,70 & 4,00 & 1,50 & 8,40 & 5,10 \\
\hline $\begin{array}{c}\text { Wheat } \\
\text { hydrolyzate }\end{array}$ & 4,20 & 5,80 & 6,30 & 3,50 & 2,80 & 0,20 & 8,30 & 2,60 \\
\hline $\begin{array}{c}\text { Flax } \\
\text { hydrolyzate }\end{array}$ & 1,45 & 1,26 & 2,27 & 0,23 & 3,50 & - & 2,01 & 1,40 \\
\hline $\begin{array}{c}\text { Sunflower } \\
\text { isolate }\end{array}$ & 4,70 & 3,38 & 6,76 & 2,20 & 4,34 & 1,00 & 9,20 & 2,20 \\
\hline $\begin{array}{c}\text { Oyster } \\
\text { mushroom }\end{array}$ & 5,00 & 3,80 & 8,80 & 7,50 & 4,20 & 1,50 & 6,90 & 5,00 \\
\hline Champignon & 8,10 & 16,40 & 14,30 & 4,30 & 4,30 & 3,20 & 5,60 & 6,20 \\
\hline Shiitake & 5,20 & 4,70 & 9,20 & 6,00 & 4,80 & 1,20 & 9,00 & 5,60 \\
\hline Enoki & 7,10 & 11,90 & 11,40 & 7,10 & 7,80 & 3,40 & 13,70 & 15,40 \\
\hline Amaranth & 4,50 & 5,60 & 4,00 & 2,40 & 3,80 & 1,60 & 7,70 & 6,40 \\
\hline $\begin{array}{c}\text { The reference } \\
\text { protein }\end{array}$ & 5,00 & 4,00 & 7,00 & $\mathbf{3 , 5 0}$ & 4,00 & 1,00 & 6,00 & $\mathbf{5 , 5 0}$ \\
\hline
\end{tabular}

Analysis of the amino acid composition indicates the presence in all proposed for the study objects of a complete set of essential amino acids. However, the content of individual amino acids is different, which was taken into account when designing blend technology for vegetarian bass products. It should be noted that amaranth proteins are sufficiently balanced in essential amino acids and, like the proteins of cultivated mushrooms, are as close as possible to fish and beef proteins. In addition, amaranth is a valuable source of squalene, a natural triterpene and an important intermediate element of sterol biosynthesis. Amaranth squalene content varies from 3.8 to $6.7 \%$. Squalene belongs to the group of carotenoids [21]. It is an indispensable component of cell membranes and is present in all cells of the body, performing a protective function for them. It serves as a source of oxygen necessary for the body, helps to normalize the processes of tissue respiration, has antimicrobial anticarcinogenic and fungicidal effects. It was noted that it is oxygen deficiency and cell destruction caused by an excess of oxidants that are the main cause of the onset and development of tumors. Thus, squalene, as a substance with antitumor activity, is able to increase the strength of the immune system, while ensuring the body's resistance to various diseases [22].

Table 1 shows that amaranth has high biological value, because its proteins contain essential amino acids. The total amaranth protein is 28$35 \%$ composed of essential amino acids [23]. Amaranth has a high content of lysine, isoleucine, tyrosine and phenylalanine.

Interesting for the development of technology was the isolate of sunflower. In terms of amino acid composition, this isolate, as well as amaranth, is as close as possible to a reference protein. It should be noted that the digestibility of sunflower protein is $90 \%$ [20].

Based on the above information, it can be predicted that blends can be developed from the presented types of vegetable protein. They will allow for the amino acid rate to replace animal proteins in the composition of sausages and to obtain products with high quality indicators and good economic effect.

Presentation of the main research material with full justification of the obtained scientific results. Vegetarian sausages are becoming 
increasingly popular in the consumer market. Their main ingredient is vegetable protein concentrates in isolated and textured form (mainly from soy, wheat and peas). This type of product is the desire to make the human diet more complete and balanced in protein. In vegetarian sausages, one can quite successfully apply the principle of complementarity to each other in the content of limiting amino acids [25].

Samples of sausages of the following composition for research were prepared: a blend consisting of mushroom powder, sunflower isolate, amaranth extract and a base. The following hydrolysates of wheat, rice, peas, and soy were chosen as the basis for the production of minced meat. During the preparation of samples, blend sausages were prehydrated at the rate of $1: 6 . .8$, depending on the basis of the minced meat. The temperature of the prepared drinking water was $18 \ldots 25^{\circ} \mathrm{C}$. The exposure time was $15 \ldots 20 \mathrm{~min}$. Then the basis for the chopped meat was prepared. The hydrolysates were poured with hot water $\left(70 \ldots 80^{\circ} \mathrm{C}\right)$, boiled for $5 \ldots 7 \mathrm{~min}$, combined with a hydrated blend, boiled for another $5 . . .7 \mathrm{~min}$ and added to the cutter, table salt, sugar, and beet juice were also added. Other ingredients were added according to the recipe. The ingredients were mixed until smooth. The sausage loaves were made, clipped and kept in suspension until completely structured for $6 . .8$ hours until completely cooled. Prototypes of products were produced using a blend in such an amount to the mass of the main raw material that would correspond to the reference protein in the total amino acid content.

The production of the control variant of cooked vegetarian sausage was carried out without the use of a blend. After analyzing the results of the organoleptic evaluation of finished products, model recipes for minced meat on various bases (hydrolysates of cereals or legumes) were created. We conducted studies of the effect of blends on the quality of finished products to determine the acceptable level of replacement of minced meat with a blend.

During the experiment, we found that the mass fraction of mushroom powder in the blends should not exceed $3 \ldots 4 \%$ of the weight of the main chopped meat, and the extract of amaranth not more than $1 \%$ of the weight of the main chopped meat. Organoleptic indicators worsened significantly with a larger application.

The composition of minced meat sausages, which contains protein components also includes the fat component. Sunflower oil was used as fat. This fact requires detailing and elaboration, since it is considered possible to use amaranth oil, coconut oil, sesame oil or a mixture of food additives E471 and E475.

An analysis of the chemical composition of sausages shows that with an increase in the level of replacement of vegetable protein (base) with a blend, especially containing amaranth and mushroom powder in an increased amount, there is a redistribution of the mass fractions of moisture, protein, fat and ash. During the adding of a blend with a high content of mushroom and amaranth, the mass fraction of fat is simultaneously reduced. Therefore, the energy value of the finished product from 128.4 to $112.5 \mathrm{kcal}$, respectively, and the proportion of carbohydrates in the experimental samples increases by an average of $2.1 \%$. The mass fraction of protein is almost unchanged in comparison with the control, but there are differences in the regulated amino acid composition.

The main quality criteria were taken to be the strength of the adhesive layer between the individual components and the water-binding ability during creating sausage meat. The free moisture that was contained in the hydrated blend and base is removed during cooking. Bound moisture is retained by protein and polysaccharide constituents. As a result of fine grinding, the particle sizes of the mushrooms and the sunflower isolate are small, but their total surface is quite large. Therefore, moisture passes from free to surface-bound and the mass loss in the fabricated samples after heat treatment was negligible (up to $5 \%$ ). Thus, the use of a blend made it possible to maintain a moisture index of $72.4 \ldots 72.8 \%$. This meets the requirements for this group of sausages.

The results of an organoleptic assessment of the quality of cooked control sausage and experimental samples using a hood are as follows: the samples had a clean, dry surface, without damage to the shell, without influxes of minced meat, the consistency was dense and became more elastic with an increase in the amount of mushroom powder in the blend. The color of minced meat in all analyzed products was pink, evenly mixed. A pinker tone was noted in the control sample without a blend.

Samples of cooked vegetarian sausage, developed without the use of a blend, did not have a delicate texture. The use of mushroom powder in the 
blend during the preparation of cooked sausage provided a good, elastic, delicate texture. Control and experimental samples were distinguished by good taste. A maximum assessment of organoleptic characteristics was noted in experimental samples with the addition of mushroom powder in an amount of $3.0 \%$. The smell of cooked sausage with the use of mushroom raw materials was also noted as "more pleasant, aromatic" on all types of bases.

No pathogenic microflora was found in control and experimental samples in microbiological studies. The total microbial number (QMAFAnM, CFU/1 g) did not exceed $1 \times 10^{2}$ per $1 \mathrm{~g}$, which indicates the safety of the products.

Thereby, the considered sunflower isolate blends containing mushroom powder and amaranth extract are a good addition to the basics of minced meat from vegetable raw materials and can be used in the technology of vegetarian sausages, in particular, cooked sausages.

Conclusions from these problems and prospects for further research in the given direction. The results of the analysis performed in the article prove the promise of using blends based on sunflower isolate using cultivated mushroom powder and amaranth extract as a good addition to the basics of hydrolysates from plant materials for approximating amino acid scores to a standard protein. Such compositions will expand the range of vegetarian sausages, the relevance of which is also outlined in the framework of this article. The developed technology of blends for vegetarian sausages allows you to simulate various recipe mixtures and improve them not only in taste, but also in amino acid composition. The resulting blends can also be used as a substitute for minced meat in the production of meat sausages, production from co-products, as well as fish.

\section{СПИСОК ВИКОРИСТАНИХ ДЖЕРЕЛ}

1. Self-declared attitudes and beliefs regarding protein sources are a good prediction of the degree of transition to a low-meat diet in France / E. Gavellea, O. Davidenko, H. Fouilleta, J. Delarueb // Appetite. - 2019. - № 142. - C. 2-9.

2. Степуро М. В. Сравнительная оценка биологической ценности белков растительного сырья / М. В. Степуро, Е. Н. Хапрова // Известия высших учебных заведений. Пищевая технология. - 2010. - № 4. - С. 34-35.

3. Антипова Л. В. Оценка потенциала источников растительных белков для производства продуктов питания / Л. В. Антипова, Л. Е. Мартемьянова. // Пищевая промышленность. - 2013. - № 8. - С. 10-12.

4. Анализ пищевой и биологической ценности высокобелковых продуктов растительного происхождения / Е. С. Бычкова, Л. Н. Рождественская, В. Д. Погорова // Хранение и переработка сельхозсырья. 2018. - № 2. - С. 53-57.

5. Віннікова Л. Г. Теорія і практика переробки м'яса / Л. Г. Віннікова. - Ізмаїл : СМИЛ, 2000. $-172 \mathrm{c}$.

6. Flavor-Enhancing Properties of Mushrooms in Meat-Based Dishes in Which Sodium Has Been Reduced and Meat Has Been Partially Substituted with Mushrooms / A. Myrdal Miller, K. Mills, T. Wong, J. Guinard // Journal of Food Science. - 2014. - № 79. - C. 795-804. DOI: $10.1111 / 1750-3841.12549$.

7. Lang M. Consumer acceptance of blending plant-based ingredients into traditional meatbased foods to reduce meat consumption: Evidence from the meat-mushroom blend / Mark Lang // Food Quality and Preference. - 2019. - № 79. - C. 47-58. DOI: 10.1016/j. foodqual.2019.103758.

8. Turp G. Y. Medicinal and edible mushrooms $\&$ usage in meat products [Електронний pecypc] / G. Y. Turp, M. Boylu. - 2018. Режим доступу: https://www.researchgate. net/publication/325296402_Medicinal_and_ edible_mushrooms_usage_in_meat_products (дата звернення 10. 09. 2019). - Назва 3 екрана.

9. Dosh K. S. Preparation of modified chicken burger by partial replacement of chicken meat with powdered of oyster mushroom and study it is physical and sensory properties / King oyster mushroom / K. S. Dosh, N. N. Tawfiq, S. H. Jabbar // The Iraqi Journal of Agricul- 
tural Sciences. - 2019. - № 47. - C. 138-143.

10. Kondratjuk N. Prospects of amaranth using in the brine systems based on uronate polysaccharides / N. Kondratjuk, T. Stepanova // Bulletin of the National Technical University "KPI". Series: Innovative research in students' scientific works. - 2018. - № 40. - C. 67-72.

11. Гащук О. I. М'ясо-рослинні напівфабрикати - комплексні повноцінні продукти харчування / О. І. Гащук, О. Є. Москалюк // Науковий вісник ЛНУВМБТ. - 2013. - № 3. - C. 2-46.

12. Патент 118438 UA, МПК A23L 13/60 (2016.01). Спосіб виготовлення м'ясних посічених напівфабрикатів / Маслійчук О. Б., Паска М. 3.; заявник Львівський національний університет ветеринарної медицини та біотехнології імені С. 3. Гжицького. - № U201701590; заявл. 20.02.2017; опубл. 10.08.2017, Бюл. № 15, 2017 p.

13. Гарбуз В. Г. Розробка технології м'ясних виробів з використанням зернових культур : автореф. дис. на здобуття наук. ступеня канд. техн. наук : спец. 05.18.04 «Технологія м'ясних, молочних та рибних продуктів» / Гарбуз Віктор Григорович. - Одеса, 2007. - 21 с.

14. Янчева М. О. Наукове обгрунтування використання композицій кріостабілізуючої дії в технології напівфабрикатів м'ясних посічених заморожених : автореф. дис. на здобуття наук. ступеня докт. техн. наук : спец. 05.18.04 «Технологія м'ясних, молочних та рибних продуктів» / Янчева Марина Олександрівна. - Одеса, 2016. - 40 с.

15. Ястреба Ю. А. Вдосконалення технології грибного напівфабрикату і комбінованих м'ясних продуктів з його використанням : автореф. дис. на здобуття наук. ступеня канд. техн. наук : спец. 05.18.16 «Технологія харчової продукції» / Ястреба Юлія Анатоліївна. - Київ, 2012. - 20 с.

16. Пешук Л. В. Перспективи використання культивованих грибів у інноваційних м'ясних продуктах / Л. В. Пешук, О. І. Гащук, О. Є. Москалюк // Обладнання та технології харчових виробництв. - 2014. № 32. - C. 171-180.

17. Разработка комплексного состава растительных белков, имеющего полноценный набор аминокислот [Електронний ресурс] // Бизнес пищевых ингредиентов. - 2018. - Режим доступу: http://bfi-online. ru/pdf/2018/2018-01.pdf (дата звернення: 29.09.2019). - Назва з екрана.

18. Воронова Н. С. Исследование химического состава и функциональных свойств белковых изолятов, полученных из подсолнечных семян и жмыха / Н. С. Воронова, А. Н. Бердина, Е. С. Кудлаева // Вестник НГИЭИ. - 2012. - № 8. - С. 38-45.

19. Prospects of cultivated mushrooms use in technology of sausages / T. Stepanova, N. Kondratjuk, N. Haijuan, K. Suprunenko // Bulletin of NTU "KhPI". Series : New solutions in modern technologies. - 2019. - № 2. - C. 75-80.

20. Баурин Д. В. Комплексная технология переработки шрота подсолнечника с получением изолята белка и углеводно-белкового корма : дис. канд. техн. наук : 03.01.06 / Д. В. Баурин - Москва, 2014. - 196 с.

21. Spanova M. Squalene - biochemistry, molecular biology, process biotechnology, and applications / M. Spanova, G. Daum // European Journal of Lipid Science and Technology. 2011. - № 113. - C. 1299-1320.

22. Gunes F. E. Medical use of squalene as a natural antioxidant / Fatma Esra Gunes // Journal of Marmara University Institute of Health Sciences. - 2013. - № 3. - C. 220-228.

23. Kalač P. Composition and nutritional value of amaranth seeds / P. Kalač, J. Moudrý // Czech Journal of Food Sciences. - 2000. - № 18. C. 201-206.

24. Ерашова Л. Д. Использование нетрадиционных источников белка растительного происхождения / Л. Д. Ерашова, Г. Н. Павлова, Р. С. Ермоленко // Пищевая промышленность. - 2009. - № 10. - C. 14-15. 


\section{REFERENCES}

1. Gavellea, E., Davidenko, O., Fouilleta, H. \& Delarueb, J. (2019). Self-declared attitudes and beliefs regarding protein sources are a good prediction of the degree of transition to a lowmeat diet in France, Appetite, Vol. 142, 2-9.

2. Stepuro, M. V. \& Haprova, Ye. N. (2010). Sravnitelnaya ocenka biologicheskoj cennosti belkov rastitelnogo syrya, Izvestija vysshih uchebnyh zavedenij. Pishhevaja tehnologija, 4, 34-35.

3. Antipova, L. V. \& Martemjanova, L. E. (2013). Ocenka potenciala istochnikov rastitelnyh belkov dlya proizvodstva produktov pitaniya, Pishchevaja promyshlennost, 8, 10-12.

4. Bychkova, E. S., Rozhdestvenskaja, L. N. \& Pogorova, V. D. (2018). Analiz pishchevoj i biologicheskoj cennosti vysokobelkovyh produktov rastitelnogo proishozhdeniya, Hranenie i pererabotka selhozsyrja, 2, 53-57.

5. Vinnikova, L. G. (2000). Teoriya i praktyka pererobky miasa, SMIL, Izmayil (in Ukrainian), 172.

6. Myrdal Miller, A., Mills, K., Wong, T. \& Guinard, J. (2014). Flavor-enhancing properties of mushrooms in meat-based dishes in which sodium has been reduced and meat has been partially substituted with mushrooms, Journal of Food Science, Vol. 79, 795-804.

7. Lang, M. (2019). Consumer acceptance of blending plant-based ingredients into traditional meat-based foods to reduce meat consumption: Evidence from the meat-mushroom blend, Food Quality and Preference, Vol. 79, 47-58.

8. Turp, G. Y., Boylu, M. (2018). Medicinal and edible mushrooms \& usage in meat products. Available at: https://www.researchgate.net/ publication/325296402_Medicinal_and_edible_mushrooms_usage_in_meat_products (accessed 10 September 2019).

9. Dosh, K. S., Tawfiq, N. N., Jabbar, S. H. \& Dosh, K. S. (2019). Preparation of modi- fied chicken burger by partial replacement of chicken meat with powdered of oyster mushroom and study it is physical and sensory properties $\square \square$ King oyster mushroom, The Iraqi Journal of Agricultural Sciences, Vol. 47, 138-143.

10. Kondratjuk, N. \& Stepanova, T. (2018). Prospects of amaranth using in the brine systems based on uronate polysaccharides, Bulletin of the National Technical University "KPI". Series: Innovative research in students' scientific works, Vol. 40, 67-72.

11. Gashhuk, O. I. \& Moskaljuk, O. Je. (2013). Myaso-roslinni napivfabrikati - kompleksni povnocinni produkti harchuvannya, Naukovyj visnyk LNUVMBT, Vol. 3, 42-46.

12. Maslijchuk, O. B. \& Paska, M. Z. L'vivs'kyj nacional'nyj universytet veterynarnoi' medycyny ta biotehnologii' imeni S.Z. G'zhyc'kogo (2017), Sposib vygotovlennja mjasnyh posichenyh napivfabrykativ, U201701590 Pat. Ukraine.

13. Harbuz, V. Г. (2007). Rozrobka tehnologii mjasnyh vyrobiv z vykorystannjam zernovyh kultur: avtoref. kand. techn. nauk, Odesa, 21.

14. Yancheva, M. O. (2016). Naukove obgruntuvannja vykorystannja kompozycij kriostabilizujuchoi dii v tehnologii napivfabrykativ mjasnyh posichenyh zamorozhenyh: avtoref. d-ra techn. nauk, Odesa, 40).

15. Jastreba, Ju. A. (2012). Vdoskonalennja tehnologii grybnogo napivfabrykatu i kombinovanyh mjasnyh produktiv z jogo vykorystannjam: avtoref. kand. techn. nauk, Kyiv, 20.

16. Peshuk, L. V., Gashhuk, O. I. \& Moskaljuk, O. Je. (2014). Perspektivi vikoristannya kultivovanih gribiv $\mathrm{u}$ innovacijnih myasnih produktah, Obladnannja ta tehnologii harchovyh vyrobnyctv, Vol. 32, 171-180.

17. Razrabotka kompleksnogo sostava rastitelnyh belkov, imeyushego polnocennyj nabor aminokislot (2018). Available at: http://bfi-online. ru/pdf/2018/2018-01.pdf (accessed 10 September 2019). 
18. Voronova, N. S., Berdina, A. N. \& Kudlaeva, E. S. (2012). Issledovanie himicheskogo sostava i funkcionalnyh svojstv belkovyh izolyatov, poluchennyh iz podsolnechnyh semyan i zhmyha, Vestnik NGIJEI, Vol. 8. 38-45.

19. Stepanova, T., Kondratjuk, N., Haijuan, N. \& Suprunenko, K. (2019). Prospects of cultivated mushrooms use in technology of sausages, Bulletin of NTU "KhPI". Series: New solutions in modern technologies, Vol. 2, 75-80.

20. Baurin, D. V. (2014). Kompleksnaja tehnologija pererabotki shrota podsolnechnika s polucheniem izo-ljata belka i uglevodnobelkovogo korma, Moscow, 196.

21. Spanova, M. \& Daum, G. (2011). Squalene - biochemistry, molecular biology, process biotechnology, and applications, European Journal of Lipid Science and Technology, Vol. 113. 1299-1320.

22. Gunes, F. E. (2013). Medical use of squalene as a natural antioxidant Fatma Esra Gunes, Journal of Marmara University Institute of Health Sciences, Vol. 3, 220-228.

23. Kalač, P. \& Moudrý, J. (2000). Composition and nutritional value of amaranth seeds, Czech Journal of Food Sciences, Vol. 18, 201-206.

24. Erashova, L. D., Pavlova, G. N. \& Ermolenko, R. S. (2009). Ispolzovanie netradicionnyh istochnikov belka rastitelnogo proishozhdeniya, Pishchevaja promyshlennost, Vol. 10, 14-15.

Х. Нан; Н. В. Кондратюк, кандидат технических наук, доцент; Т. М. Степанова, кандидат технических наук, доцент; А. В. Афанасьев; Е. И. Сытник; А. В. Дышук; Е. Е. Супруненко (Сумской национальный аграрный университет). Технология блендов на основе растительного белка для производства вегетарианских колбасных изделий.

Аннотация. Статья посвящена актуальной на сегодняшний день теме дефицита белка в организме человека. В представленном обзоре кратко изложены основные результаты исследований по оценке свойств белков культивированных грибов и амаранта. Высокая биологическая ценность белков позволяет получать смеси (бленды), которые могут быть использованы для производства вегетарианских колбас, обладающих улучшенными фуннциональными свойствами. В статье приведена возможность разработки технологии блендов на основе растительного сырья за счет внесения растительного сырья, обладающего высокой биологической ценностью. Разработанные бленды будут иметь сбалансированный аминокислотный состав и будут содержать повышенное количество сквалена.

Ключевые слова: дефицит белка, культивированные грибы, амарант, вегетарианские колбасы, сквален.

Х. Нан; Н. В. Кондратюк, кандидат технічних наук, доцент; Т. М. Степанова, кандидат технічних наук, доцент; О. В. Афанасьєв; К. І. Ситник; А. В. Дишук; К. Є. Супруненко (Сумський національний аграрний університет). Технологія блендів на основі рослинного білка для виробництва вегетаріанських ковбасних виробів.

Анотація. Статтю присвячено актуальній на сьогодні темі дефіциту білка в організмі людини, що, зокрема, зумовлено зниженням споживання м'ясних і молочних продуктів, навіть у країнах із високим рівнем доходу населення. Ефективність обміну білків в організмі людини значною мірою залежить від їх якісної і кількісної присутності в їжі. У разі надходження білків нижче рекомендованих норм в організмі починають розпадатися білки тканин. Досить важливою стала розробка збалансованих за амінокислотним складом продуктів, що виготовляються з доступної сировини. Якість харчового білка характеризується, перш за все, його біологічною цінністю, ступенем чистоти утилізації, амінокислотним складом, коефіцієнтом перетравності. Відсутність у їжі хоча б однієї незамінної амінокислоти стає причиною негативного азотистого балансу, викликає порушення діяльності центральної нервової системи, може призвести до зупинки росту, важких клінічних наслідків. Окрім цього, у матеріалах статті наведено шляхи розширення асортименту вегетаріанських ковбасних виробів, у тому числі й за рахунок використання блендів із сировини вітчизняного (регіонального) походження. У сучасній м'ясопереробній галузі не зупиняється пошук додаткових джерел білкової та біл- 
кововмісної сировини. Проте, і напрям, що окреслює виробниитво вегетаріанських ковбас, також потужно розвивається і є перспективним для багатьох країн світу. Однак, проблема засвоєння білка в цьому аспекті набуває гостроти за рахунок незбалансованого амінокислотного складу рослинних компонентів. У представленому огляді коротко викладено основні результати досліджень щодо оцінки властивостей білків культивованих грибів, амаранту та ізоляту соняшника як інгредієнтів, що здатні провести регуляцію амінокислотного балансу гідролізатів зернових і бобових, які використовуються в якості основ для виробництва вегетаріанських варених ковбас. Висока біологічна цінність білків амаранту, соняшника, культивованих грибів дозволяє отримувати суміші (бленди), які можуть бути використані для виробництва вегетаріанських ковбас, що володіють поліпшеними функціональними властивостями. У статmі наведено принципи створення блендів на основі рослинної сировини для виготовлення вегетаріанських ковбасних виробів із високою біологічною цінністю. Розроблені бленди матимуть збалансований склад амінокислот та міститимуть підвищену кількість сквалену. У ході експериментального дослідження опрацьовано спосіб підготовки та внесення блендів до складу основи фраршів для вегетаріанських варених ковбас, якими виступають гідролізати бобових, злакових і зернових культур. Проведено органолептичні випробування готової продукції, розроблено оптимальні співвідношення вмісту компонентів блендів для високих показників якості та харчової цінності готового продукту.

Ключові слова: дефріцит білка, культивовані гриби, амарант, вегетаріанські ковбаси, сквален. 